\title{
The introduced barnacle Balanus glandula (Darwin) in the Mar del Plata port as a structuring species in the intertidal community ${ }^{1}$
}

\author{
Rodolfo Elías y Eduardo Alberto Vallarino \\ Departamento de Ciencias Marinas, Universidad Nacional de Mar del Plata \\ Dean Funes 3350, 7600, Mar del Plata, Argentina. \\ E-mail: roelias@mdp.edu.ar y evallari@mdp.edu.ar
}

Recibido: 18 noviembre 1998; versión corregida: 4 octubre 2000; aceptado: 16 noviembre 2000

\begin{abstract}
The paper deals with the distribution pattern and population dynamics of the introduced barnacle Balanus glandula in the intertidal areas of Mar del Plata port. The reproductive cycle of this barnacle is discussed as a community structuring force. Replicated areas in both the high intertidal and the upper mid intertidal zones were monthly denuded. The recruitment, cumulative settlement, mortality and growth of $B$. glandula were recorded, as well as the succession pattern of the associated fauna. First settlement of B. glandula occurred in winter (July). Succession begins with a film of microorganisms followed by green algae (Ulva lactuca and Enteromorpha spp.) which dominate up to a final stage of $B$. glandula dominated community is reached all along the intertidal. B. glandula densities were significantly higher in the mid intertidal than in the high intertidal (19600 and 13600 ind. $\mathrm{m}^{-2}$, respectively). Annual mean mortality was high in the port (up to $62 \%$ ) but heavy settlement allowed a final density 4 times greater than in the upper mid intertidal of exposed rocky shores, and twice the greatest density reached in the Northern Hemisphere. Winter reproduction of $B$. glandula, absence of predators, and the neutral or beneficial effect of algae allows this species to occupy in wave protected areas the whole intertidal zone, displacing the former B. amphitrite populations from the intertidal to the subtidal. In exposed rocky shores the species outcompete mussels from the high intertidal, establishing the typical barnacle fringe.
\end{abstract}

Key words: Balanus glandula, intertidal, successional pattern, port, Southwestern Atlantic.

\section{El cirripedio introducido Balanus glandula (Darwin) en el puerto de Mar del Plata como una especie estructurante de la comunidad intermareal}

RESUMEN. Se analiza la dinámica poblacional del cirripedio introducido Balanus glandula en el área intermareal del puerto de Mar del Plata. El ciclo reproductivo de este cirripedio es discutido como una fuerza estructurante de la comunidad. Áreas replicadas, tanto en el intermareal alto como en la parte superior del intermareal, fueron mensualmente desnudadas. El reclutamiento, asentamiento acumulativo, mortalidad y crecimiento basal medio de B. glandula fue registrado, al igual que la sucesión de la fauna asociada. El primer asentamiento se registró en invierno (julio). La sucesión comenzó con un film de microorganismos, seguido por algas verdes (Ulva lactuca y Enteromorpha spp.) que dominaron hasta una comunidad final dominada por B. glandula a lo largo de todo el intermareal. La densidad de $B$. glandula fue significativamente más alta en la parte superior del intermareal medio que en el intermareal alto (19.600 y 13.600 ind. $\mathrm{m}^{-2}$, respectivamente). La mortalidad anual media fue grande en el puerto (más del 62\%), pero elevados asentamientos permitieron una densidad final 4 veces mayor respecto a la zona rocosa expuesta al oleaje y dos veces superior a la mayor densidad alcanzada en el hemisferio norte. La reproducción invernal de $B$. glandula, la ausencia de predadores y el efecto benéfico o neutral de algas, permiten a esta especie ocupar la totalidad del intermareal, desplazando a las poblaciones de $B$. amphitrite del intermareal al submareal. En el intermareal rocoso expuesto al oleaje, la especie excluye a los bivalvos sólo del intermareal alto, formando la clásica franja de cirripedios.

Palabras claves: Balanus glandula, intermareal, patrón sucesional, puerto, Atlántico sudoccidental.

\footnotetext{
${ }^{1}$ Contribución Científica $N^{\circ} 113$ Departamento de Ciencias Marinas, UNMdP.
} 


\section{INTRODUCTION}

The original descriptions of the intertidal rocky shore communities of Mar del Plata ( $38^{\circ} 02^{\prime} \mathrm{S}, 57^{\circ} 32^{\prime} \mathrm{W}$ ) showed the total absence of barnacles from the intertidal zone. This pattern was also typical from others intertidal rocky shores of the Southwestern Atlantic coasts (Ringuelet et al., 1962; Olivier et al., 1966a, 1966b) and also for some places of México and Venezuela (Rodríguez, 1959, 1963; Villalobos, 1960; Nonato and Peres, 1961; Rodriguez da Costa, 1962 in Olivier et al., 1966b).

In the late 60's barnacles colonized the port of Mar del Plata (Bastida, 1968), and expanded to the natural surroundings rocky shores (Bastida, 1971a; Penchaszadeh, 1973; Spivak et al., 1975). Thereafter the intertidal zone at the port was dominated by Balanus amphitrite amphitrite (Darwin), with small patches of Brachidontes rodriguezi (Bastida et al., 1971). Successive studies showed that barnacle dominance persisted (Bastida, 1971a; b; Spivak et al., 1975; Bastida et al., 1980). Today, B. amphitrite recruit and is dominant on subtidal panels at the port (Pezzani et al., 1994), while recruitment seems to occur often also in the intertidal. However, Spivak et al. (1975) detected in the intertidal areas of the port another unidentified dominant species of Balanus. In 1974 B. glandula was identified from the waterline of experimental panels placed in the port (Bastida et al., 1980). Further studies showed that this species occupied all the intertidal areas of the port (Elias et al., 1993; Vallarino and Elias, 1997).

Balanus glandula is a prominent barnacles on the high intertidal communities on the Pacific rocky coasts, from Baja California to Alaska (Morris et al., 1980 in Gaines et al., 1985; Foster et al., 1991), but there is no information on their populations dynamics in the South Atlantic coasts. The goal of the present study was to contribute to understanding on how could this species colonize an area previously occupied by another barnacle. In order to do so, we studied the patterns of recruitment, growth, and mortality of Balanus glandula in the sheltered rocky shores of Mar del Plata Port, and followed the community succession pattern. We also discuss how this species has affected the intertidal community structure.

\section{MATERIAL AND METHODS}

From January to December of 1991 four sampling units of $100 \mathrm{~cm}^{2}$ each were monthly denuded in the inner part of the north breakwater of Mar del Plata Port (Fig. 1). One pair of sampling units was located in the High Intertidal (HI) and the other pair in the Upper Mid Intertidal (UMI). Irregular quarcitic blocks introduced from surrounding sites and located in breakwaters like structures compose this sheltered intertidal area.

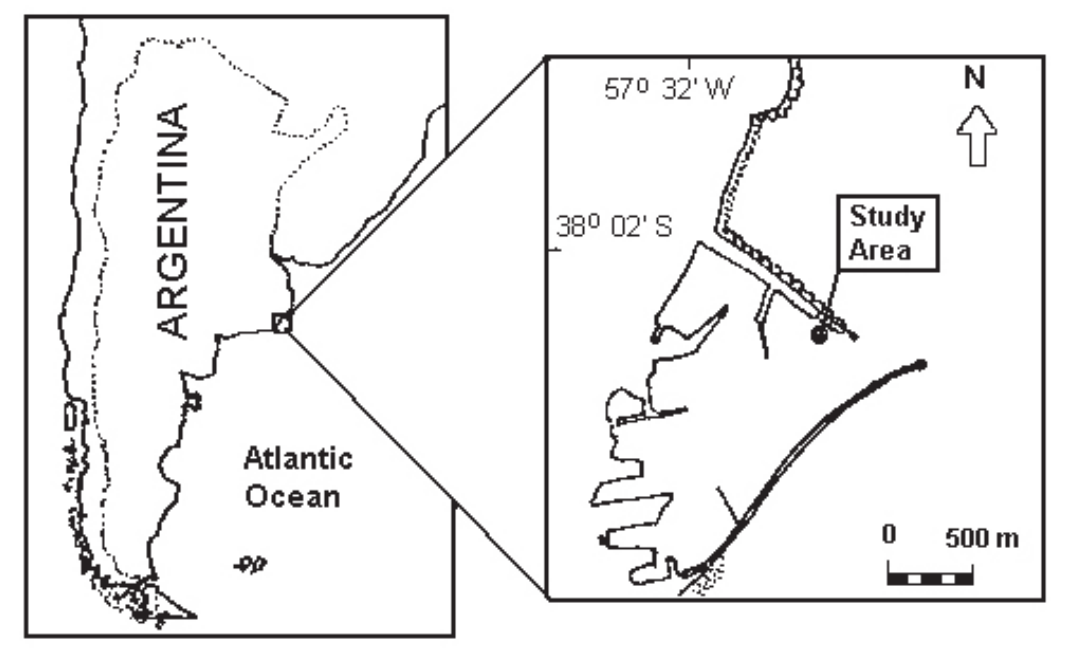

Figure 1. Location of sampling site in the inner part of the north breakwater of the Mar del Plata Port (sheltered area).

Figura 1. Ubicación del sitio de muestreo en la parte interna de la escollera norte del puerto de Mar del Plata (área protegida). 
Denuded areas were controlled monthly, by superposing a plastic film with 100 random points to detect percent cover and settlement time of Balanus glandula, other barnacle species, and associated macrofauna (Connell, 1970). For associated macroflora relative percent cover was assessed according to the following categories: 1 , $0-25 \% ; 2,26-50 ; 3,51-75 ; 4,76-100$ of total surface area covered

For detecting changes in the population parameters of Balanus glandula other 4 fixed sampling units (two at the HI, and two at the UMI) were denuded in January 1991 and controlled monthly until March 1992. We were not able to measure cyprid settlement, so the censuses were carried out in barnacles $>0.5 \mathrm{~mm}$ in basal diameter (recruits). Barnacle recruitment, cumulative recruitment (surving individuals from one month to the next), and mortality were determined monthly. Growth was measured by drawing the basal diameter of each individual every month on a plastic film (following Connell, 1961). Differences between means number of recruits, cumulative recruitment and growth were compared with "a priori" test (orthogonal contrast) in a simple ANOVA test design.

\section{RESULTS}

The successional pattern began with the establishment of a initial microfilm, wich was observed but not quantified. Green algae (mainly Ulva lactuca (L) and some Enteromorpha spp.) colonized all the denuded space throughout the year in both the High Intertidal (HI) and the Upper Mid Intertidal (UMI) (Tables 1 and 2). The pulmonate limpet Siphonaria lessoni Blainville migrated into the denuded area, reaching high relative cover, although this species prefers the edge of denuded areas than the areas themselves, so its occurrence was occasional and the data were not included in the present study. The only intertidal barnacle species present was $B$. glandula, except for a few barnacles of uncertain identification (perhaps B. improvisus) that settled in sampling units in April, but died whiting the first month.

Most areas denuded between January and June

Table 1. Relative percent cover of Ulva lactuca - Enteromorpha spp. in the high intertidal of the Mar del Plata port in 1991.

Tabla 1. Porcentaje de cobertura relativa de Ulva lactuca-Enteromorpha spp. En el intermareal alto del puerto de Mar del Plata en 1991.

\begin{tabular}{|c|c|c|c|c|c|c|c|c|c|c|c|}
\hline JAN & FEB & MAR & APR & MAY & JUN & JUL & AUG & SEP & OCT & NOV & DEC \\
\hline A & & 4 & 3 & 3 & 3 & 4 & 4 & 4 & 4 & 4 & 4 \\
\hline \multirow[t]{23}{*}{ B } & & 1 & 1 & 1 & 1 & 2 & 2 & 2 & 4 & 4 & 4 \\
\hline & C & 4 & 4 & 4 & 4 & 4 & 4 & 4 & 4 & 4 & 4 \\
\hline & $\mathrm{D}$ & 1 & 1 & 2 & 2 & 3 & 4 & 4 & 4 & 4 & 4 \\
\hline & & E & 4 & 4 & 4 & 4 & 4 & 4 & 4 & 4 & 4 \\
\hline & & F & & 2 & 2 & 2 & 2 & 2 & 4 & 4 & 4 \\
\hline & & & $\mathrm{G}$ & 2 & 1 & 1 & 1 & 2 & 3 & 4 & 4 \\
\hline & & & $\mathrm{H}$ & 2 & 1 & 2 & 2 & 2 & 4 & 2 & 4 \\
\hline & & & & I & 1 & 1 & 1 & 2 & 3 & 4 & 4 \\
\hline & & & & $\mathrm{J}$ & 1 & 1 & 1 & 1 & 2 & 3 & 4 \\
\hline & & & & & K & & & 1 & 4 & 4 & 4 \\
\hline & & & & & $\mathrm{L}$ & & & 1 & 4 & 4 & 4 \\
\hline & & & & & & M & & 1 & 1 & 2 & 2 \\
\hline & & & & & & $\mathrm{N}$ & & 1 & 1 & 1 & 1 \\
\hline & & & & & & & $\mathrm{O}$ & & 1 & 4 & 4 \\
\hline & & & & & & & $\mathrm{P}$ & & 2 & 4 & 4 \\
\hline & & & & & & & & Q & & & 1 \\
\hline & & & & & & & & $\mathrm{R}$ & & & 1 \\
\hline & & & & & & & & & S & & 1 \\
\hline & & & & & & & & & $\mathrm{T}$ & & 1 \\
\hline & & & & & & & & & & $\mathrm{U}$ & \\
\hline & & & & & & & & & & $\mathrm{V}$ & \\
\hline & & & & & & & & & & & W \\
\hline & & & & & & & & & & & $X$ \\
\hline
\end{tabular}


Table 2. Relative percent cover of Ulva lactuca - Enteromorpha spp. in the upper mid intertidal of the Mar del Plata port in 1991.

Tabla 2. Porcentaje de cobertura relativa de Ulva lactuca - Enteromorpha spp. En la parte superior del intermareal medio del puerto de Mar del Plata en 1991.

\begin{tabular}{|c|c|c|c|c|c|c|c|c|c|c|c|}
\hline JAN & FEB & MAR & APR & MAY & JUN & JUL & AUG & SEP & OCT & NOV & DEC \\
\hline A & & 4 & 4 & 4 & & & & & & & \\
\hline \multirow[t]{23}{*}{ B } & & & 1 & 2 & 2 & 4 & 4 & 4 & 4 & 4 & 4 \\
\hline & C & & & & & & & & & & \\
\hline & $\mathrm{D}$ & 1 & 2 & 3 & 3 & 4 & 4 & 4 & 3 & 4 & 4 \\
\hline & & E & 1 & 1 & 1 & 1 & 1 & 2 & 4 & 4 & 4 \\
\hline & & $\mathrm{F}$ & & 1 & 1 & 3 & 3 & 3 & 3 & 3 & 4 \\
\hline & & & G & & 1 & 1 & 1 & 2 & 3 & 3 & 4 \\
\hline & & & $\mathrm{H}$ & & 1 & 2 & 4 & 4 & 4 & 4 & 4 \\
\hline & & & & I & 1 & 1 & 2 & 3 & 4 & 4 & 4 \\
\hline & & & & $\mathrm{J}$ & 1 & 1 & 2 & 4 & 4 & 4 & 4 \\
\hline & & & & & K & & & 1 & 4 & 4 & 4 \\
\hline & & & & & $\mathrm{L}$ & & & 1 & 4 & 4 & 4 \\
\hline & & & & & & M & & 1 & 2 & 4 & 4 \\
\hline & & & & & & $\mathrm{N}$ & & 1 & 2 & 4 & 4 \\
\hline & & & & & & & $\mathrm{O}$ & & 1 & 2 & 2 \\
\hline & & & & & & & $\mathrm{P}$ & & & 4 & 4 \\
\hline & & & & & & & & Q & & 2 & 2 \\
\hline & & & & & & & & $\mathrm{R}$ & & 2 & 2 \\
\hline & & & & & & & & & S & & 1 \\
\hline & & & & & & & & & $\mathrm{T}$ & & 1 \\
\hline & & & & & & & & & & $\mathrm{U}$ & \\
\hline & & & & & & & & & & $\mathrm{V}$ & \\
\hline & & & & & & & & & & & W \\
\hline & & & & & & & & & & & $X$ \\
\hline
\end{tabular}

Table 3. Relative porcent cover of Balanus glandula in the high intertidal of Mar del Plata Port in 1991. The + symbol represent presence of juvenile barnacles lesser than $0.5 \mathrm{~mm}$ in basal diameter.

Tabla 3. Porcentaje de cobertura relativa en 1991 de Balanus glandula en el intermareal alto del puerto de Mar del Plata. El símbolo + representa la presencia de juveniles de menos de 0,5 mm en diámetro basal.

\begin{tabular}{|c|c|c|c|c|c|c|c|c|c|c|c|}
\hline JAN & FEB & MAR & APR & MAY & JUN & JUL & AUG & SEP & OCT & NOV & DEC \\
\hline A & & & & & & & & & & 2 & 4 \\
\hline \multirow[t]{23}{*}{ B } & & & & & & & 1 & 2 & 1 & 2 & 5 \\
\hline & $\mathrm{C}$ & & & & & & 5 & 10 & 23 & 25 & \\
\hline & $\mathrm{D}$ & & & & & & 2 & & 2 & 2 & 11 \\
\hline & & E & & & & & 2 & & 6 & 4 & 8 \\
\hline & & $\mathrm{F}$ & & & & & + & 4 & 5 & 6 & 1 \\
\hline & & & G & & & & + & & 3 & 4 & 3 \\
\hline & & & $\mathrm{H}$ & & & & + & & 3 & 6 & 5 \\
\hline & & & & I & & & & & 5 & 6 & 9 \\
\hline & & & & $\mathrm{J}$ & & & & & 1 & 3 & 7 \\
\hline & & & & & K & & & & 2 & 7 & 7 \\
\hline & & & & & $\mathrm{L}$ & & & 1 & 2 & 3 & 7 \\
\hline & & & & & & M & & & & 2 & 4 \\
\hline & & & & & & $\mathrm{N}$ & & & 2 & & 2 \\
\hline & & & & & & & $\mathrm{O}$ & & + & 1 & \\
\hline & & & & & & & $\mathrm{P}$ & & + & & \\
\hline & & & & & & & & Q & & & \\
\hline & & & & & & & & $\mathrm{R}$ & & & \\
\hline & & & & & & & & & S & & \\
\hline & & & & & & & & & $\mathrm{T}$ & & \\
\hline & & & & & & & & & & $\mathrm{U}$ & \\
\hline & & & & & & & & & & V & \\
\hline & & & & & & & & & & & W \\
\hline & & & & & & & & & & & $X$ \\
\hline
\end{tabular}


Table 4. Relative percent cover of Balanus glandula in the upper mid intertidal of Mar del Plata Port in 1991. The + symbol represent presence of juvenile barnacles lesser than $0.5 \mathrm{~mm}$ in basal diameter.

Tabla 4. Porcentaje de cobertura relativa de Balanus glandula en la parte superior del intermareal medio del puerto de Mar del Plata en 1991. El símbolo + representa la presencia de juveniles de menos de $0,5 \mathrm{~mm}$ en diámetro basal.

\begin{tabular}{|c|c|c|c|c|c|c|c|c|c|c|c|}
\hline JAN & FEB & MAR & APR & MAY & JUN & JUL & AUG & SEP & OCT & NOV & DEC \\
\hline \multicolumn{12}{|l|}{ A } \\
\hline B & & & & & & & & & 1 & 1 & 5 \\
\hline & C & & & & & & & & & & \\
\hline & D & & & & & + & 1 & & 20 & 28 & \\
\hline & & E & & & & + & 2 & & 9 & 10 & 19 \\
\hline & & $\mathrm{F}$ & & & & 2 & 4 & 9 & 22 & 28 & 28 \\
\hline & & & $\mathrm{G}$ & & & & + & + & 18 & 20 & 25 \\
\hline & & & $\mathrm{H}$ & & & 3 & 8 & & 33 & 35 & 38 \\
\hline & & & & I & & & + & 2 & 9 & 5 & 21 \\
\hline & & & & $\mathrm{J}$ & & & 2 & 4 & 7 & 10 & 14 \\
\hline & & & & & K & & & + & 9 & 7 & 3 \\
\hline & & & & & L & & & 2 & 2 & 5 & 4 \\
\hline & & & & & & M & & & & 3 & 2 \\
\hline & & & & & & $\mathrm{N}$ & & & & 1 & 5 \\
\hline & & & & & & & $\mathrm{O}$ & & + & + & + \\
\hline & & & & & & & $\mathrm{P}$ & & + & + & + \\
\hline & & & & & & & & Q & & & \\
\hline & & & & & & & & $\mathrm{R}$ & & & \\
\hline & & & & & & & & & S & & \\
\hline & & & & & & & & & $\mathrm{T}$ & & \\
\hline & & & & & & & & & & $\mathrm{U}$ & \\
\hline & & & & & & & & & & V & \\
\hline & & & & & & & & & & & W \\
\hline & & & & & & & & & & & $X$ \\
\hline
\end{tabular}

1991 were colonized by B. glandula between JulySeptember. Areas denuded in late winter or spring were scarcely colonized by B. glandula or not colonized at all, suggesting that rocky substrata needs at least two winter months of initial film development to became attractive for a barnacle settlement. Rate of recruitment was variable between and within tidal levels.

Recruitment showed no statistical differences between tidal levels, with a peak in July-September (Fig. 2, Table 5). Cumulative recruitment increasing sharply during the first months, with no differences

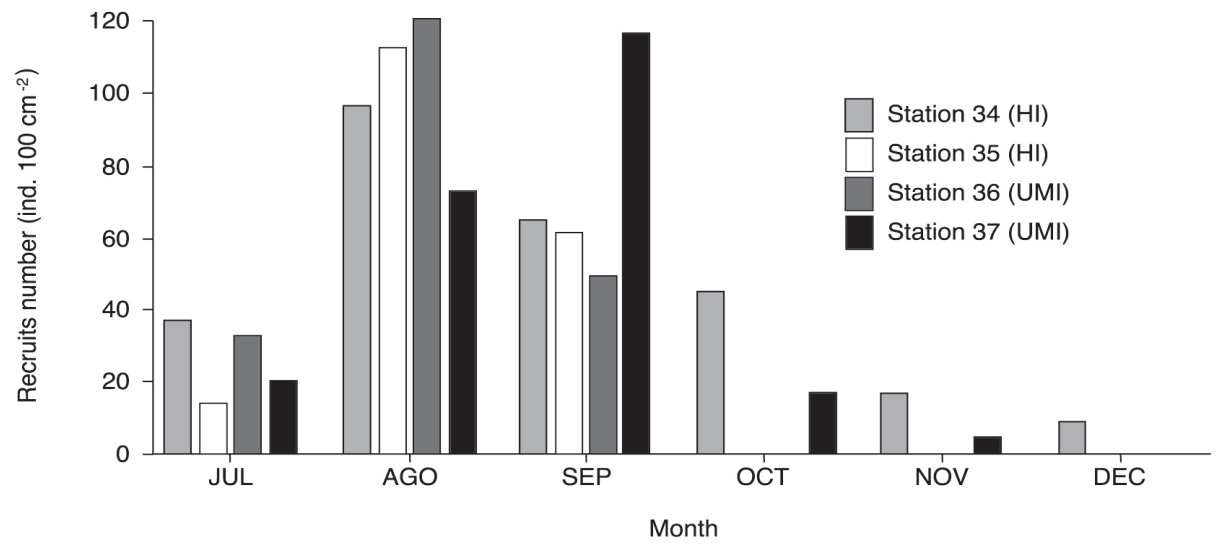

Figure 2. Recruitment of individuals of Balanus glandula $(0.5 \mathrm{~mm}$ in basal diameter) in the high intertidal (HI, Sations 34-35) and upper mid intertidal (UMI, St. 36-37) of the Mar del Plata port.

Figura 2. Individuos reclutados de Balanus glandula $(0,5 \mathrm{~mm}$ de diámetro basal) en el intermareal alto (HI, Estaciones 34-35) y parte superior del intermareal medio (UMI, Estaciones 36-37) en el puerto de Mar del Plata. 


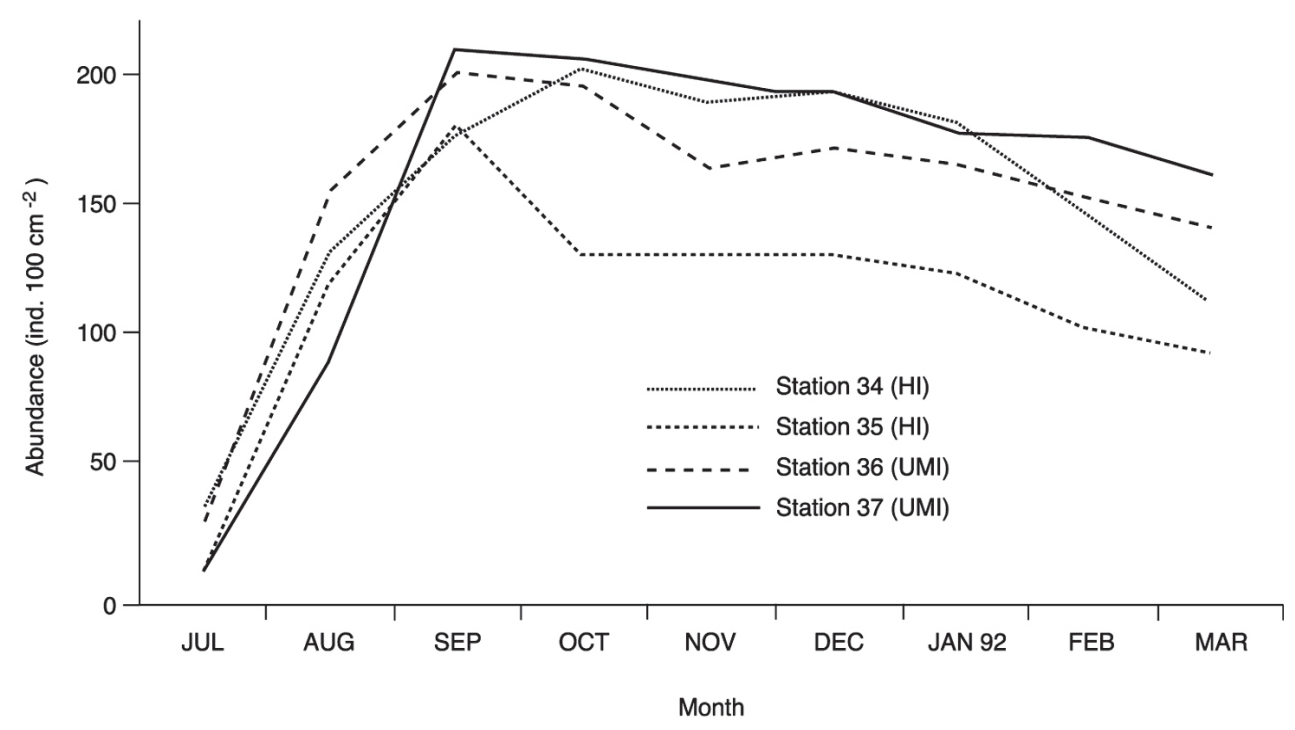

Figure 3. Cumulative recruitment of Balanus glandula in the high intertidal (HI, St. 34-35) and upper mid intertidal (UMI, Stations 36-37) of the Mar del Plata Port.

Figura 3. Asentamiento acumulativo de Balanus glandula en el intermareal alto (HI, Estaciones 34-35) y parte superior del intermareal medio (UMI, Estaciones 36-37) en el puerto de Mar del Plata.

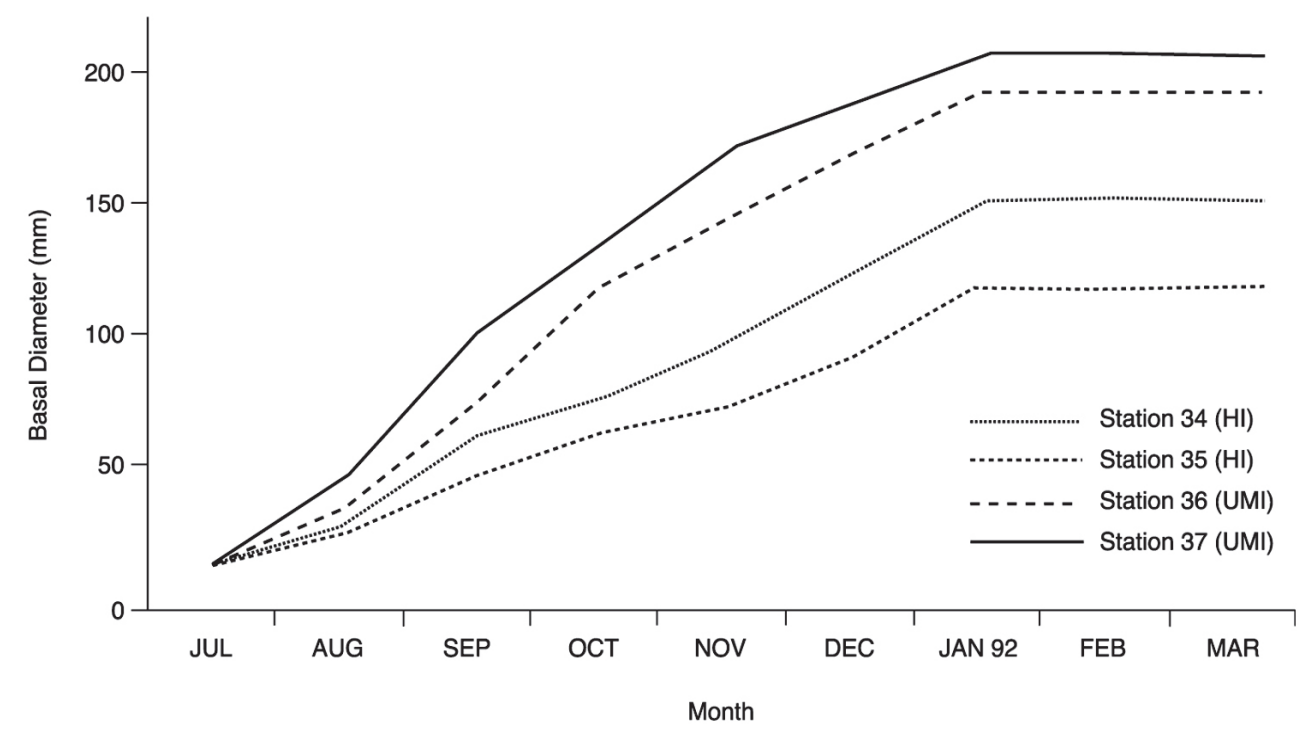

Figure 4. Mean basal diameter of Balanus glandula as a function of time in the high intertidal (HI, St. 34-35) and upper mid intertidal (UMI, Stations 36-37) of the Mar del Plata Port.

Figura 4. Diámetro basal medio de Balanus glandula en función del tiempo en el intermareal alto (HI, Estaciones 34-35) y parte superior del intermareal medio (UMI, Estaciones 36-37) en el puerto de Mar del Plata. 
Table 5. Analysis of variance. Orthogonal contrast in the Mar del Plata port. HI: high intertidal, UMI: upper mid intertidal. ns: no significative; $* * \mathbf{p}<0.01$

Tabla 5. Análisis de Varianza. Contrastes ortogonales en el puerto de Mar del Plata. HI: intermareal alto; UMI: parte superior del intermareal medio. ns: no significativa; $* * \mathbf{p}<0,01$

\begin{tabular}{|cccc|}
\hline SOURCE & SUM & Fd & F \\
\hline Recruitment HI vs. UMI & 100 & 1 & $0.07 \mathrm{~ns}$ \\
Cumulative Recruitment HI vs. UMI & 41412.25 & 1 & $3.54 \mathrm{~ns}$ \\
Mean Basal Growth HI vs. UMI & 2762.5 & 1 & $127.2 * *$ \\
\hline
\end{tabular}

$\mathrm{F}_{0.05}=4.00$

$\mathrm{F}_{0.01}=7.08$

between HI and UMI (Fig. 3, Table 5). The growth of $B$. glandula was higly significative different in the two levels (Fig. 4, Table 5). At high densities, basal growth was practically null due to crowding and individual grew in height rather than in width.

During spring (October-December) mean mortality reached values between 3.4 and $21 \%$, but being great in autumn (March) with a maximum of $23 \%$ of total individuals. Mean cumulative mortality was different between the HI $(62,1 \%)$ and the UMI $(27,1 \%)$. However, mortality appeared to have little effect on the $B$. glandula population due to the high final densities, between 13600 to 19600 ind. m-2 reaching densities several times greater than in the Northern Hemisphere.

\section{DISCUSSION}

Recruitment of Balanus glandula occurs during winter months (July) in the Mar del Plata Port area. First record for colonization by $B$. glandula were reported in 1974, when they settled in artificial panels between August to November, with a maximum in September (Bastida et al., 1980). This pattern was also reported for open sea rocks (Spivak and L'Hoste, 1976; Nugent, 1986; Vallarino and Elías, 1997). Isolated individuals of B. glandula covering $0.03 \%$ of intertidal substrata (an abrasion platform) near a sewage was recorded in autumn and winter, $200 \mathrm{~km}$ south of Mar del Plata (Lopez Gappa et al., 1993).

During winter month, mean water temperature decrease from 17 to $8^{\circ} \mathrm{C}$ in the Mar del Plata port (Bastida, 1971a, 1971b; Lopez Gappa et al., 1993). In British Columbia B. glandula spawns twice between May-September (Wu and Levings, 1979), when water temperature is $9-14^{\circ} \mathrm{C}$ (Dill and Gillett, 1991). Foster et al. (1991) mention for the Northeast Pacific a mean water temperature along the coast
(N-S) from 7.9 to $17.9^{\circ} \mathrm{C}$. So the spawning period in Mar del Plata area occurs in a similar range of temperature. Hines (1978) mentions that in British Columbia and Southern California this species broods during late fall and early winter, and that cold water temperature is necessary for trigged the reproduction.

The winter recruitment in the Mar del Plata area suggests a breeding season approximately in JuneJuly. In Blanca Bay estuary a winter-spring larval peak of Balanus glandula was observed in the plankton, but no time fixation was established (Wagner et al., 1991). The larvae of Balanus glandula in Northern Hemisphere are estimated to be in the plankton for approximately 3 to 4 weeks (Brown and Roughgarden, 1985). Initial larvae release by $B$. glandula adults is generally in early spring (Connell, 1970; Gaines et al., 1985), or with two spawning periods between May-September ( $\mathrm{Wu}$ and Levings, 1979).

Variation of recruitment density of Balanus glandula among different habitats can be considered as a combination of two processes, planktonic larval supply and water movement. Gaines et al. (1985) suggest that settlement density variation is more likely to be a function of planktonic larval supply other than of characteristics of either the local water column or substratum. Grosberg (1982) demonstrated that cyprids of B. glandula are zoned even before settlement, and within their ranges of planktonic zonation, larvae may still select substrata. Bastida et al. (1980) also suggested this pattern for barnacle larvae in Mar del Plata Port. On the other hand, variations in rate of settlement on closely adjacent areas were also great in the study carried out by Connell (1961).

In Mar del Plata area mortality reached high values in sites with heavy recruitment (high vs low tidal levels). Population structure of Balanus 
glandula in central California differs between locations of high and low larval settlement rate. At the low settlement locations mortality of barnacles is independent of the area, while at high settlement locations mortality is cover-dependent due to increased predation by starfish on areas of high barnacle cover (Gaines and Roughgarden, 1985). On the other hand, B. glandula recruited throughout much of the intertidal zone in Washington, but at lowest levels they die within 1 year, mainly due to predation, before reaching adulthood (Connell, 1970), and mortality was density independent at both high and low shore levels (Connell, 1985). However, the absence of both predators and interspecific competence in the Mar del Plata port suggest the existence of a denso-dependent relationship in the high level (barnacle fringe) of this intertidal zone.

Relative basal growth was highly different between HI and UMI. However, in both levels, crowding interrupted the basal growth, and individuals became taller. These crowded barnacles developed an elongate morphology that is more susceptible to disturbance (Grant, 1977). Large disturbance results since barnacles are attached to each other wash off in clumps (Farrell, 1989). Although the port is a sheltered area, autumn and winter storms and the high densities of barnacles may create bare space in barnacles crowded rocks, allowing the next recolonization cycle.

\section{Community pattern}

Barnacles have an aggressive behavior in hard substrates occupation by ship-borne populations (remote dispersal), or larval natural drift along the coast (marginal dispersal) (see Lewis, 1976), and constitute the most common marine species invading harbors worldwide.

The successful introduction of the barnacles Balanus amphitrite and B. trigonus (Darwin) in the Mar del Plata port could be considered as examples of remote dispersal, and have been attributed to their tolerance to organic enrichment and water turbidity (Bastida, 1971a; Bastida et al., 1971). The settlement of $B$. amphitrite and B. trigonus occurs in the port during January (summer), when water temperature reaches $20^{\circ} \mathrm{C}$. The heaviest recruitment of these species occurred in mid-February (with a mean density of 122 ind. $\mathrm{m}^{-2}$ ) and in mid-January (25 ind. $\mathrm{m}^{-2}$ ), respectively (Bastida et al., 1980), but both disappeared during June (Bastida, 1971a, 1971b). Although $B$. amphitrite can attained $5 \mathrm{~cm}$ width in summer months (Bastida 1971a, 1971b), the winter reproductive cycle of $B$. glandula allows it to settled and reach a similar size at summer time, when other barnacle settle, and occupied the available space with a high density.

In exposed rocky shores of Southern California mean density of B. glandula was reported to reach 205 ind. $\mathrm{m}^{2}$ (Littler et al., 1991), and a recently study reported a maximum of 7000 ind. $\mathrm{m}^{-2}$ (Lohse, 1993), half of the densities found in the Mar del Plata port. This density can be attributed to a larger larval availability and a lower water movement in the port which is likely to produce heavier settlement. Other factor to be considered is that $B$. glandula can persist in spatial refuges in sheltered intertidal of the port due to their tolerance to physical stress (including pollution) and the absence of both predators and interspecific competence (Stephens and Bertness, 1991).

The main space competitor of $B$. amphitrite and B. trigonus in the waterline of Mar del Plata Port was the green algae Enteromorpha intestinalis (L.), while the pulmonate limpet Siphonaria lessoni browsing create bare space for barnacle colonization (Bastida, 1971a). Although Enteromorpha has an annual cycle, their colonization is interrupted during cold months (Bastida, 1971b; Bastida et al., 1980). Limpets could also reduce the density of barnacle settlement or damage young barnacles by detachment (bulldozing effect or running over) (Dayton, 1971; Miller and Carefoot, 1989; Safriel et al., 1994). However, a preliminary study in the intertidal areas of the port shows no significative interactions between S. lessoni and B. glandula population, due to the capacity of the limpet to raise the vertical wall of barnacles, avoiding the bulldozing effect (Elias et al., 1993).

In Mar del Plata area, canopy algae were absent. The opportunistic green algae in the port, and the red encrusting algae Hildenbrandia in exposed rocky shores (Playa Grande beach) seem to have a neutral or a beneficial effects on the B. glandula population. However other studies have shown barnacle reduction due to algal frond whipping (Menge, 1976; Grant, 1977) or inhibition of B. glandula settlement by mucus or an unsuspected negative cue associated with algal mucus (Jonhson and Strathman, 1989). In fact, $H$. lecanellieri Harriot has been mentioned as a seral stage in the successional pattern of the exposed rocky intertidal community (Penchaszadeh, 1973; Nugent, 1986).

In summary, predator absence, no negative interactions with algae or limpets, wave-caused 
disturbance, growth, and recruitment pattern relationships allow Balanus glandula to successfully colonize Mar del Plata Port area. On exposed rocky shores B. glandula displaced the BrachidontesMytilus community only from the high intertidal (barnacle fringe), because mytilids are better competitors in the mid intertidal (Vallarino and Elías, 1997), while in the Port they became dominant all along the intertidal, displacing the former invading (barnacles Balanus amphitrite and B. trigonus) to the subtidal.

\section{AKNOWLEDGEMENTS}

The Mar del Plata National University through a Grant (subsidio $N^{\circ} 100 / 92$ ) from their Secretaría de Ciencia y Técnica (SECYT) financed this work. We are indeed to Dr. Ricardo Bastida (CONICETUNMdP) for critical reading of the manuscript, and to three anonymous reviewers that improved the manuscript.

\section{REFERENCES}

Bastida, R. 1968. Preliminary notes of the marine fouling at the port of Mar del Plata (Argentina). Compte Rendu 2nd International Congress on Marine Fouling and Corrosion, Athens, Grece, pp. 557-562.

Bastida, R. 1971a. Las incrustaciones biológicas en el puerto de Mar del Plata. Período 1966/67. Rev. Mus. Arg. Cien. Nat. "Bernardino Rivadavia", Hidrobiología, 3(2); 203-285.

Bastida, R. 1971b. Las incrustaciones biológicas en las costas Argentinas. La fijación mensual en el puerto de Mar del Plata durante tres años consecutivos. Corrosión y Protección, 2(1): 1-17.

Bastida, R., D.A. Capezzani and M.R. Torti. 1971. Fouling organisms in the port of Mar del Plata (Argentine). I: Siphonaria lessoni (Blainville, 1824). Ecological and biometric aspects. Mar. Biol., 10: 297-307.

Bastida, R., M. Trivi de Mandri, V. Lichtschein de Bastida and M. Stupak. 1980. Ecological aspects of Marine Fouling at the Port of Mar del Plata (Argentina). V Congreso Internacional de Corrosion Marina e Incrustaciones. Secc. Biol. Mar., pp. 299-320.
Brown, S.K. and J. Roughgarden. 1985. Growth, Morphology, and laboratory culture of larvae of Balanus glandula (Cirripedia: Thoracica). J. Crust. Biol., 5(4): 574-590.

Connell, J.H. 1961. Effects of competition, Predation by Thais lapillus, and other factors on natural population of the barnacle B. balanoides. Ecol. Monogr., 31: 61-104.

Connell, J.H. 1970. A predator-prey system in the marine intertidal region. I: Balanus glandula and several species of Thais. Ecol. Monogr., 40: 4978.

Connell, J.H. 1985. The concequences of variation of initial settlement vs. post-settlement mortality in rocky intertidal communities. J. Exp. Mar. Biol. Ecol., 93: 11-45.

Dayton, P.K. 1971. Competition, Disturbance and community organization: the provision and subsequent utilization of space in a rocky intertidal community. Ecol. Monogr., 41: 351-389.

Dill, L.M. and J.F. Gillett. 1991. The economic logic of barnacle Balanus glandula (Darwin) hiding behaviour. J. Exp. Mar. Biol. Ecol., 153: 115-127.

Elías, R., J.P. Martin and E.A. Vallarino. 1993. Observaciones sobre el comportamiento de Siphonaria lessoni (Gastropoda: Siphonariidae) en el intermareal del puerto de Mar del Plata. Res. $3^{\text {as }} \mathrm{J}$. Nac. Ciencias del Mar, Puerto Madryn, Argentina, p. 75 (abstract).

Farrell, T.M. 1989. Succession in a rocky intertidal community: the importance of disturbance size and position whitin a disturbed patch. J. Exp. Mar. Biol. Ecol., 128: 57-73.

Foster, M.S., A.P. de Vogelaere, J.S. Oliver, J.S. Pearse and C. Harrold. 1991. Open coast intertidal and shallow subtidal ecosystems of the northeast pacific. In: A.C. Mathieson and P.H. Nienhuis (eds.). Intertidal and Littoral Ecosystems, Elsevier, New York, pp. 235-272.

Gaines, S. and J. Roughgarden. 1985. Larval settlemen rate: A leading determinant of structure in an ecological community of the marine intertidal zone. Proc. Natl. Acad. Sci., 82: 3707-3711.

Gaines, S., S. Brown and J. Roughgarden. 1985. Spatial variation in larval concentrations as a cause of spatial variation in settlement for the barnacle, Balanus glandula. Oecologia (Berlin), 67: 267-272. 
Grant, W.S. 1977. High intertidal community organization on a rocky headland in Maine, USA. Mar. Biol., 44: 15-25.

Grosberg, R.K. 1982. Intertidal zonation of barnacles: The influence of planktonic zonation of larvae on vertical distribution of adults. Ecology, 63(4): 894899.

Hines, A.H. 1978. Reproduction in three species of intertidal barnacles from central California. Biol. Bull., 154: 262-281.

Johnson, L.E. and R.R. Strathmann. 1989. Settling barnacle larvae avoid substrata previously occupied by a mobile predator. J. Exp. Mar. Biol. Ecol., 128(1): 87-103.

Lewis, J.R. 1976. The ecology of rocky shores. Hodder \& Stoughton, London, 323 pp.

Littler, M.M., D.S. Littler, S.N. Murray and R.R. Seapy. 1991. Southern California rocky intertidal ecosystems. In: A.C. Mathieson and P.H. Nienhuis (eds.). Intertidal and littoral ecosystems, Elsevier, New York, pp. 235-272.

Lohse, D.P. 1993. The importance of the secondary substratum in a rocky intertidal community. J. Exp. Mar. Biol. Ecol., 166: 1-17.

Lopez Gappa, J.J., A. Tablado and N. Magaldi. 1993. Seasonal changes in an intertidal community affected by sewage pollution. Environ. Pollut., 82: 157-165.

Menge, B.A. 1976. Organization of the New England rocky intertidal community: role of predation, competition, and environmental heterogeneity. Ecol. Monogr., 46: 355-393.

Miller, K.M. and T.H. Carefoot. 1989. The role of spatial and size refuges in the interactions between juvenile barnacles and grazing limpets. J. Exp. Mar. Biol. Ecol., 134: 157-174.

Nugent, P. 1986. Ecología y biología de los mejillinares de Brachydontes rodriguezi (D'Orb., 1846) en el litoral bonaerense. Tesis Doctoral, La Plata National University, 86 pp.

Olivier, S.R., I.K. de Paternoster and R. Bastida. 1966a. Estudios biocenóticos de las costas del Chubut (Argentina). I: Zonación biocenológica de Puerto Pardelas (Golfo Nuevo). Bol. Inst. Biol. Mar., 10: 5-71.
Olivier, S.R., A. Escofet, J.M. Orensanz, S.E. Pezzani, A.M. Turro and M.E. Turro. 1966 b. Contribución al conocimiento de las comunidades bénticas de Mar del Plata. I: El litoral rocoso entre playa Grande y playa Chica. An. Com. Invest. Cient. Prov. Buenos Aires, 7: 185-206.

Penchaszadeh, P. 1973. Ecología de la comunidad del Mejillín (Brachydontes rodriguezi, D’Orb.) en el mediolitoral rocoso de Mar del Plata (Argentina): el proceso de recolonización. Physis A, 32 (84): 51-64.

Pezzani, S., M. Perez and M. Stupak. 1994. Macrofauling community at Mar del Plata harbour (1991-92): Recruitment and Structure. Anales CIDEPINT, pp. 39-51.

Ringuelet, R., A. Amor, N. Magaldi and R. Pallares. 1962. Estudio ecológico de la fauna intercotidal de puerto Deseado en febrero de 1961 (Santa Cruz, Argentina). Physis, 23(64): 35-53.

Safriel, U.N., N. Erez and T. Keasar. 1994. How do limpets mantain barnacle-free submerged artificial surfaces? Bull. Mar. Sci., 54(1): 17-23.

Spivak, E.D., R. Bastida, G. L'Hoste and H. Adabbo. 1975. Los organismos incrustantes del puerto de Mar del Plata. II. Biología y ecología de Balanus amphitrite y Balanus trigonus (CrustaceaCirripedia). LEMIT (anales), 3: 41-124.

Spivak, E.D. and S.G. L'Hoste. 1976. Presencia de cuatro especies de Balanus en la costa de la Provincia de Buenos Aires. Distribución y aspectos ecológicos. Edición impresa a cargo de los autores, Mar del Plata, 17 pp.

Stephens, E.G. and M.D. Bertenss. 1991. Mussel facilitation of barnacle survival in a sheltered bay habitat. J. Exp. Mar. Biol. Ecol., 145: 33-48.

Vallarino, E.A. and R. Elías. 1997. The dynamics of an introduced Balanus glandula population in the southwestern Atlantic rocky shores. The consequences on the intertidal community. Publ.Staz. Zool. Napoles, Mar. Ecol., 18(4): 319-335.

Wagner, J.M., M. Hoffmeyer and L. Tejera. 1991. Estudio preliminar sobre la bioecología de Balanidae (Cirripedia, Thoracica) del estuario de Bahía Blanca, Argentina. Res. 2 ${ }^{\text {as }}$ J. Cienc. Mar, Puerto Madryn, p. 41 (abstract).

Wu, R.S. and C.D. Levings. 1979. Energy flow and population dynamics of the barnacle Balanus glandula. Mar. Biol., 54: 83-89. 